\title{
Intraglomerular fibronectin accumulation and degradation in obese Zucker rats
}

\author{
L. Paczek, M. Teschner, R. M. Schaefer and A. Heidland \\ Department of Medicine, Division of Nephrology, Medical University Würzburg, Würzburg, FRG
}

\begin{abstract}
Summary. The obese Zucker rat is a classic model of non-immune mediated spontaneous focal glomerulosclerosis. An important initiating hallmark of glomerulosclerosis in this model is mesangial matrix expansion. Fibronectin, a highly biologically active glycoprotein, is a normal constituent of mesangial extracellular matrix. Using a quantitative method based on enzyme immunoassay we assessed the intraglomerular fibronectin content and its degradation in obese Zucker rats and their lean littermates. In the obese Zucker rats the glomerular fibronectin content was significantly higher in comparison to the controls ( $88 \pm 6 \mathrm{vs} 48 \pm 4 \mathrm{ng} / 10^{3}$ glomeruli). Furthermore, proteinase activity against fibronectin was sig-
\end{abstract}

nificantly reduced in the glomeruli of obese Zucker rats when compared to control animals (at pH 5.4: $186 \pm 6 \mathrm{U} / \mathrm{mg}$ protein vs $286 \pm 14 \mathrm{U} / \mathrm{mg}$ protein, at $\mathrm{pH} 7.4: 152 \pm 12 \mathrm{U} / \mathrm{mg}$ protein vs $193 \pm 12 \mathrm{U} / \mathrm{mg}$ protein). These data demonstrate that in obese Zucker rats there is a glomerular accumulation of fibronectin which we propose is at least partly due to diminished proteolytic digestion. Whether accumulation of intraglomerular fibronectin contributes to progressive glomerulosclerosis remains a matter of debate.

Key words: Fibronectin, diabetes mellitus, isolated glomeruli.
The obese Zucker rat is an accepted model of non-immune mediated spontaneous focal glomerulosclerosis [1]. Obese Zucker rats are characterized by mild glucose intolerance and peripheral insulin resistance which result from obesity and hyperlipidaemia [2]. The pathogenesis of glomerulosclerosis in this animal model has been the subject of discussion, but glomerular protein accumulation seems to be one important feature of this event [3]. Both glomerular structural proteins i.e. mesangial matrix as well as glomerular basement membrane, and deposited plasma proteins are part of the glomerular protein accumulation.

The balance of glomerular proteins depends either on their synthesis and deposition or their degradation. Recently, we demonstrated in obese Zucker rats that overall intraglomerular proteolytic activity was reduced [4] and we speculated that this might be an important underlying reason for glomerular protein accumulation. However, this was demonstrated only with the aid of a non-specific substrate. The aim of this study is to refine these results by investigating the metabolism of fibronectin, an important glomerular structural protein. We investigated, whether fibronectin accumulates in the glomeruli of obese Zucker rats and whether this might be due to diminished intraglomerular degradation of this substance.

\section{Materials and methods}

Obese and lean male Zucker rats used in the study were obtained from Fa. Ivanovas (Kisslegg/Allgäu, FRG). The rats were fed on standard rodent chow and killed at 16 weeks of age.

\section{Preparation of isolated glomeruli}

The animals were anaesthetized with hexobarbital $(150 \mathrm{mg} / \mathrm{kg}$ body weight) and a mid-abdominal incision was made to expose both kidneys. The kidneys were rapidly removed and bisected longitudinally. The medulla was excised and the cortical tissue was minced. Isolated rat glomeruli were obtained by differential sieving as essentially described by Spiro (5) by passing the homogenate successively through a $100 \mu \mathrm{m}$ nylon sieve (Swiss Silk, Blothing Cloth MfG Co. Ltd., Zürich, Switzerland) which excludes tubules and blood vessels. The sieved tissue was suspended in ice-cold $0.9 \% \mathrm{NaCl}$ poured onto a $150 \mu \mathrm{m}$ sieve and the final sieving procedure was done through a $50 \mu \mathrm{m}$ sieve which retained the glomeruli. The retained glomeruli were removed from the sieve with the aid of ice-cold $0.9 \% \mathrm{NaCl}$, the suspension was gently spun at $400 \mathrm{~g}$ for $5 \mathrm{~min}$ and the final pellet kept for morphological examination to exclude significant tubular contamination and for counting of the glomeruli. As judged by light microscopy, highly purified preparations of intact glomeruli were obtained from all groups of animals. Following lysis, the samples were stored at $-30^{\circ} \mathrm{C}$. All assays were performed $24 \mathrm{~h}$ after isolation of the glomeruli. 


\section{Analytical methods}

Materials. Leupeptin, aprotinin, EDTA and E-64 [trans-Epoxysuccinyll-leucylamido (4 ganidino) butane] were purchased from Sigma (München, FRG) as were BSA (bovine serum albumin), OPD (ophenylenediamine) and PBS (phosphate buffered saline). Human plasma fibronectin was from Gibco (Grand Island, N. Y., USA) and rabbit anti-fibronectin serum labelled with HRP (horseradish peroxidase) was from Dako (Hamburg, FRG).

Nylon wool, type $200 \mathrm{~L}$ scrubbed, was from Du Pont (Boston, Mass. USA).

Flat-bottom polystyrole microplates were from Falcon (Heidelberg, FRG). Additional reagents: carbonate buffer $\mathrm{pH} 9.6$ and citrate buffer $\mathrm{pH} 4.5,100 \mathrm{mmol} / 1$ Tris $\mathrm{pH} 5.4$ and $100 \mathrm{mmol} / \mathrm{l}$ Tris pH 7.4. The ELISA-reader for microplates was from Behring (Marburg, FRG).

\section{Enzyme-linked immunoassay for fibronectin-digestion}

ELISA for fibronectin digestion was based on the method described previously [6]. In order to assay the panel of enzymes which might digest fibronectin, the homogenate was processed as follows: firstly, the sample was centrifuged at $400 \mathrm{~g}$ for $10 \mathrm{~min}$ to remove all debris, non-disrupted cells and nuclei [7].

Secondly, proteins with adhesive properties were removed by adsorption onto nylon wool. Nylon wool was packed in to $5 \mathrm{ml}$ polypropylene syringes into which the cell homogenate was poured. After 30 -min incubation at $+4{ }^{\circ} \mathrm{C}$ the suspension was recovered. In a preliminary study it was demonstrated (data not shown) that $95 \%$ of fibronectin was removed from the solution at a range of up to $1000 \mathrm{ng} / \mathrm{ml}$. To measure fibronectin digestion, fibronectin coatedmicroplates were used. $30 \mathrm{ng} / 100 \mu \mathrm{l}$ of fibronectin diluted in carbonate buffer $\mathrm{pH} 9.6$ was poured into wells and dried overnight at $39^{\circ} \mathrm{C}$. Concomitantly, samples of fibronectin in concentrations of $5 \mathrm{ng} / \mathrm{well}, 15 \mathrm{ng} / \mathrm{well}, 20 \mathrm{ng} / \mathrm{well}, 25 \mathrm{ng} / \mathrm{well}$ and $30 \mathrm{ng} / \mathrm{well}$ were included in each plate to provide a standard curve. Dried plates were incubated for $2 \mathrm{~h}$ in $1 \% \mathrm{BSA}$ in PBS at $37^{\circ} \mathrm{C}$ in a humid atmosphere and plates were washed three times with $0.05 \%$ Tween 20 in $0.15 \mathrm{~mol} / 1 \mathrm{NaCl}$. Plates prepared in this manner were stored at $+4^{\circ} \mathrm{C}$ until used for assay after not more than 12 weeks.

In order to determine the optimal concentration of antigen (fibronectin) a preliminary study was performed in which microplates were coated with serially diluted fibronectin (range 1-1500 ng/well) and incubated with serially diluted anti-fibronectin antibody (in the range 1:500-1:6000). The absorbtion rate was linear up to $30 \mathrm{ng}$ fibronectin per well.

To perform the digestion test $100 \mu \mathrm{l}$ of sample diluted 1:1 (volume/volume) in Tris buffer was placed in fibronectin-coated-microplates. After $90-\mathrm{min}$ incubation at $37^{\circ} \mathrm{C}$ plates were washed three times with $0.05 \%$ Tween 20 -saline and then incubated for $60 \mathrm{~min}$ with anti-fibronectin rabbit antibody labelled with HRP dilution $1: 2000$ in $0.05 \%$ Tween 20 and $0.5 \%$ BSA in PBS. After washing three times the colour was developed with the aid of $0.4 \mathrm{mg} / \mathrm{ml} \mathrm{OPD}$ in citrate buffer $\mathrm{pH} 4.5$ supplemented with $0.03 \% \mathrm{H}_{2} \mathrm{O}_{2}$. The colour reaction was stopped after $10 \mathrm{~min}$ with $6 \mathrm{~N} \mathrm{H}_{2} \mathrm{SO} 4$ and optical density was measured at $492 \mathrm{~nm}$ with the aid of an ELISA-reader.

For convenience the proteolytic activity is expressed such that one unit will hydrolyze $1 \mathrm{ng}$ of fibronectin per min at $37^{\circ} \mathrm{C}$.

In order to study whether the fibronectin digestion by the glomerular proteinases is sensitive to different $\mathrm{pH}$ values of the incubation medium, all proteinase assays were conducted in the range of 5.47.4. Hence, the preparations of lysed glomeruli were incubated at $37^{\circ} \mathrm{C}$ in the presence of buffers with different $\mathrm{pH}$ values.

\section{Enzyme-linked immunoassay for fibronectin-content}

Fibronectin content was estimated in homogenate of sonicated disrupted glomeruli as described previously [8]. The probe was diluted 1:40 in carbonated buffer $\mathrm{pH} 9.6$ containing proteinase inhibitors:
Table 1. Blood chemistry and urinary protein excretion in obese Zucker rats and lean littermates

\begin{tabular}{lcc}
\hline & $\begin{array}{l}\text { Control lean } \\
\text { Zucker rats } \\
(n=10)\end{array}$ & $\begin{array}{l}\text { Obese } \\
\text { Zucker rats } \\
(n=10)\end{array}$ \\
\hline Body weight $(\mathrm{g})$ & $300 \pm 4$ & $495 \pm 7^{\mathrm{c}}$ \\
Plasma urea $(\mathrm{mmol} / \mathrm{l})$ & $2.66 \pm 0.09$ & $3.49 \pm 0.08^{\mathrm{a}}$ \\
Plasma creatinine $(\mathrm{mmol} / \mathrm{l})$ & $35.36 \pm 1.77$ & $35.36 \pm 1.76$ \\
Plasma protein $(\mathrm{g} / \mathrm{l})$ & $5.3 \pm 0.1$ & $5.6 \pm 0.1$ \\
Plasma glucose $(\mathrm{mmol} / \mathrm{l})$ & $10.87 \pm 0.28$ & $11.54 \pm 0.49$ \\
Plasma triglyceride $(\mathrm{mmol} / \mathrm{l})$ & $0.991 \pm 0.08$ & $5.7 \pm 0.35^{\mathrm{c}}$ \\
Plasma cholesterol $(\mathrm{mmol} / \mathrm{l})$ & $2.553 \pm 0.08$ & $3.43 \pm 0.15^{\mathrm{b}}$ \\
Urinary protein excretion $(\mathrm{mg} / 24 \mathrm{~h})$ & $8.5 \pm 0.8$ & $14 \pm 3.5$ \\
\hline
\end{tabular}

Values are given as means \pm SEM.

${ }^{\mathrm{a}} p<0.05 ;{ }^{\mathrm{b}} p<0.01 ;{ }^{\mathrm{c}} p<0.001$, obese Zucker vs lean Zucker rats

$1 \mu \mathrm{g} / \mathrm{ml}$ leupeptin, $1 \mu \mathrm{g} / \mathrm{ml}$ aprotinin, $0.5 \mu \mathrm{g} / \mathrm{ml} \mathrm{E}-64$ and $1 \mathrm{mmol} / \mathrm{l}$ EDTA. Both proteinase inhibitors and high $\mathrm{pH}$ were used in order to prevent protein degradation by enzymes [9]. Dilution of the probe in the range of 1:20-1:100 provided linear data.

A $100 \mu \mathrm{l}$ portion of each probe in triplicate was placed on the flatbottom microplate wells and dried overnight at $37^{\circ} \mathrm{C}$. Samples of fibronectin in concentrations of $2.5 \mathrm{ng}, 5 \mathrm{ng}$ and $10 \mathrm{ng}$ per well were included in each plate to provide a standard curve. Dried plates were incubated for $2 \mathrm{~h}$ with $1 \% \mathrm{BSA}$ in water at $37^{\circ} \mathrm{C}$ in a humid atmosphere in order to saturate the plates and then washed three times with $0.05 \%$ Tween 20 in $0.15 \mathrm{mmol} / \mathrm{l} \mathrm{NaCl}$.

One hundred microlitres of rabbit anti-fibronectin serum labelled with HRP diluted 1:1000 in 1\% BSA-PBS was added to the microplate and incubated for $60 \mathrm{~min}$ at $37^{\circ} \mathrm{C}$. After washing three times $100 \mu \mathrm{l}$ of the substrate solution (OPD with $0.03 \% \mathrm{H}_{2} \mathrm{O}_{2}$ in citrate buffer) was put into each well and incubated for $10 \mathrm{~min}$ at room temperature. The reaction was stopped by adding $100 \mu$ of $6 \mathrm{~N}$ $\mathrm{H}_{2} \mathrm{SO}_{4}$, and the optical density was measured at $492 \mathrm{~nm}$ with the aid of a ELISA-reader $[10]$.

Protein was determined according to the method of Lowry et al.

Total urinary protein excretion was determined with the aid of the biuret method. Biochemical parameters of the blood were assayed using a Technicon autoanalyzer (Technicon, Terrytron, NY, USA).

\section{Statistical analysis}

Statistical analysis was performed by Student's $t$-test. Significance was determined as $p<0.05$. All results are given as means \pm SEM.

\section{Results}

As can be seen in Table 1, there was no difference in the plasma values of creatinine and blood urea nitrogen among the experimental animals. However, as expected, plasma triglycerides and plasma cholesterol levels were significantly enhanced in the obese Zucker rats in comparison to controls. The levels of fibronectin content, either depicted as value per glomeruli or estimated as fibronectin amount per protein content, are shown in Figure $1 \mathrm{~A}$ and $\mathrm{B}$ respectively. In fact, the fibronectin content per glomeruli was significantly $(p<0.01)$ increased in obese Zucker rats in comparison to their lean littermates ( $88 \pm 6$ vs $48 \pm 4 \mathrm{ng} / 10^{3}$ glomeruli). Similarly, the relative fibronectin concentration, with respect to protein content, was significantly increased in the experimental animals 

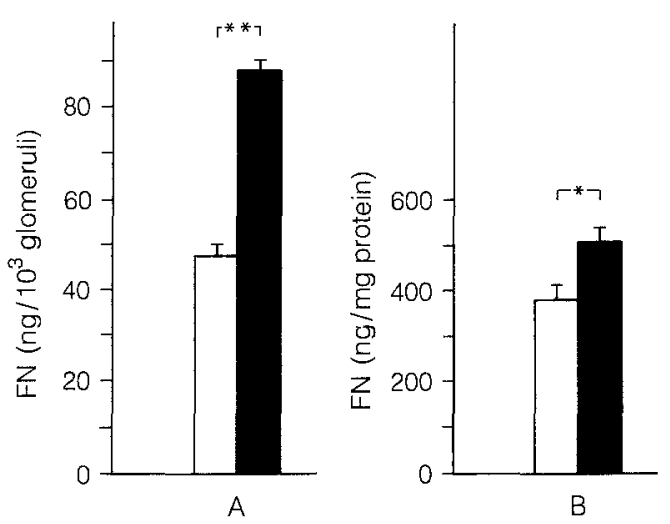

Fig. 1. A Comparison of fibronectin (FN) content in obese Zucker rats ( $\square$ ) vs lean controls $(\square)$ when fibronectin content is expressed as $\mathrm{ng} / 10^{3}$ glomeruli. Results expressed as mean \pm SEM. $* p<0.05$; $* * p<0.01$; obese Zucker vs control rats. B Comparison of fibronectin content in obese Zucker rats ( $\square$ ) vs lean controls $(\square)$, when fibronectin content is expressed as $\mathrm{ng} / \mathrm{mg}$ protein

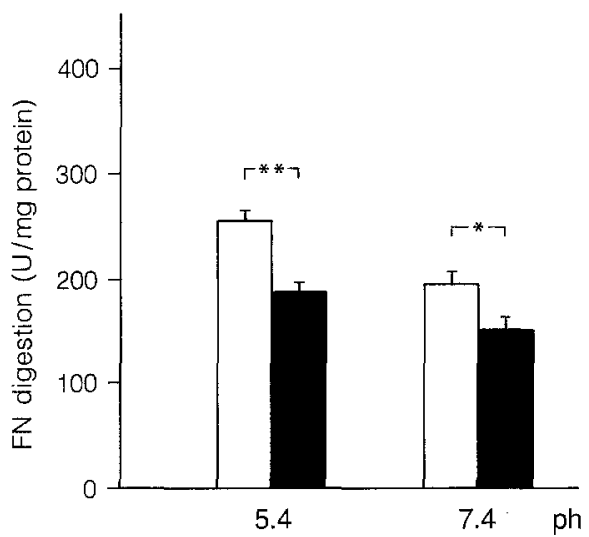

Fig. 2. Comparison of intraglomerular fibronectin (FN) digestion at acidic and neutral $\mathrm{pH}$, when activity is expressed as $\mathrm{U} / \mathrm{mg}$ protein. (For details see Methods and Results). Results expressed as mean \pm SEM. Obese Zucker rats $(\square)$, vs lean control rats $(\square)$ $* p<0.05 ; * *<<0.01$

( $505 \pm 28 \mathrm{ng} / \mathrm{mg}$ protein) in comparison to the control group ( $383 \pm 33 \mathrm{ng} / \mathrm{mg}$ protein).

As can be seen in Figure 2, the proteinase activity against fibronectin at $\mathrm{pH} 5.4$ was significantly $(p<0.01)$ reduced in the kidneys from obese Zucker rats compared to controls $(186 \pm 6 \mathrm{U} / \mathrm{mg}$ protein vs $256 \pm 14 \mathrm{U} / \mathrm{mg}$ protein). Similar results were obtained at neutral $\mathrm{pH}$ $(152 \pm 12 \mathrm{U} / \mathrm{mg}$ protein vs $193 \pm 12 \mathrm{U} / \mathrm{mg}$ protein for obese Zucker rats vs lean controls).

\section{Discussion}

Fibronectin is a large glycoprotein, built of two subunits which are cross-linked by disulphide-binding [11]. It is synthesized by a wide variety of cells in vitro, but in vivo it is mainly produced by fibroblasts and endothelial cells [12]. Fibronectin, which is a normal constituent of plasma, is also widely deposited in connective tissue, blood vessel walls and basement membranes, being a major non-collagenous component of organ stroma $[13,14]$. The biological properties of tissue fibronectin are numerous. For instance, it pro- motes both adherence and motility of fibroblasts [15]. Perturbation of the glomeruli by the accumulation of fibronectin with high biological activity may induce both proliferation of mesangial cells and expansion of mesangial matrix $[16,17]$. Hence, a potential accumulation of fibronectin might be an important promotor of focal glomerulosclerosis. Interestingly, we did in fact demonstrate in the model of obese Zucker rats enhanced glomerular concentrations of this glycoprotein. A similar result has been demonstrated in the model of streptozotocin diabetes [18], however, it has been argued that fibronectin is mainly trapped in the glomerular basement membrane. Moreover, it could be argued, that the glomerular cells have increased their libronectin production in the obese Zucker rat model. In itro, production of fibronectin by glomerular cells [19] has heen demonstrated. Additionally, increased biosynthesis if fibronectin by endothelial cells [20] and by fibroblasts [21] has been reported in diabetes mellitus.

In the present study, we have also demonstrated the accumulation of fibronectin in isolated glomeruli in obese Zucker rats. This finding holds true either when relating the intraglomerular fibronectin value to a certain amount of glomeruli or to the intraglomerular protein content. Although not having assessed the diameter of the glomeruli in the present study, one must take into account the potentially different glomerular size of our experimental animals, which would influence the data concerning the content of this glomerular glycoprotein. Therefore, we confirmed the result of increased glomerular fibronectin values in obese Zucker rats by re-calculating it per protein content.

When discussing this effect, enhanced trapping of plasma fibronectin as well as stimulated synthesis of this glycoprotein are possible mechanisms which cannot be excluded. Since in contrast to the animals with streptozotocin-diabetes [22] the intraglomerular haemodynamics are unaltered in obese Zucker rats [23], a deposition of plasma constituents to different extents in obese and lean rats does not seem to be the most probable explanation. The possible contribution of reduced catabolism of fibronectin to its glomerular accumulation has not yet been established. In fact, the glomerulus, formally described only as an ultrafilter, is well equipped with proteolytic enzymes, which are involved in the degradation of structural and non-structural proteins [24]. It has been argued in the model of streptozotozin diabetes, that fibronectin accumulation might be due to enhanced glycosylation, a change which reduces the susceptibility of proteins to proteolytic digestion [25].

In this study we demonstrated that the activity of proteinases involved in the degradation of fibronectin from normal serum is significantly reduced. This was studied at pH 5.4 and 7.4, at the pH-optimum of cytosolic thiol proteinases and neutral serine and metallo-proteinases such as collagenase or trypsin. All these enzymes have been demonstrated in glomeruli. Possible mechanisms for the reduced proteinase activity might be due to enhanced glycosylation of the involved proteolytic enzymes or increased concentrations of proteinase inhibitors.

Our data indicate that fibronectin accumulation is partly due to reduced intraglomerular degradation. This 
mechanism could be an important pathogenic factor in the development of glomerulosclerosis in obese Zucker rats.

Acknowledgements. The excellent technical assitance of Mrs. M. Roeder and expert secretarial assistance of Mrs. Ch. Winter and Mrs. E. Frohmüller are gratefully acknowledged.

\section{References}

1. Kasiske BL, Cleary MP, O'Donnel MP, Keane WF (1985) Effects of genetic obesity on renal structure and function in the Zucker rat. J Lab Clin Med 106: 598-604

2. Zucker LM (1965) Hereditary obesity in the rat associated with hyperlipidemia. Ann NY Acad Sci 131: 447-458

3. Klahr S, Schreiner G, Ichikawa I (1988) The progression of renal disease. N Eng J Med 318: 1657-1666

4. Teschner M, Paczek L, Schaefer RM, Heidland A (1991) Obese Zucker rat: potential role of intraglomerular proteolytic enzymes in the development of glomerulosclerosis. Res Exp Med (in press)

5. Spiro RG (1967) Studies on the renal glomerular basement membrane. Preparation and chemical composition. J Biol Chem 242: 1915-1919

6. Cooper TW, Bauer EA, Eisen AZ (1983) Enzyme-linked Immunosorbent Assay for human skin collagenase. Collagen Rel Res 3: 205-216

7. Haapatanta T, Gustafsoon JA, Glauman H (1983) Isolation of mitochondrial lysosomes and mitosomes from rat ventral prostate with a note on inverted microsomal vesicles. Arch Biochem Biophys 223: 458-467

8. Rennard SI, Berg R, Martin GR, Foidard JM, Robey PG (1980) Enzyme-linked Immunoassay (ELISA) for connective tissue components. Anal Biochem 104:205-214

9. North MJ (1989) Prevention of unwanted proteolysis. In: Baynon RJ, Bond JS (eds), Proteolytic enzymes. Oxford University Press, London, pp 105-124

10. Lowry OH, Rosebrough NJ, Farr AC, Randall RJ (1951) Protein measurements with the Folin phenol reagent. J Biol Chem 193: 265-275

11. Ruoslahti E (1988) Fibronectin and its receptors. Ann Rev Biochem 57:375-413

12. Hynes RO, Yamada KM (1982) Fibronectins: multifunctional modular glycoproteins. J Cell Biol 95: 369-377

13. Stathakis N, Fountas A. Tsianos E (1981) Plasma fibronectin in normal subjects and in various disease states. J Clin Pathol 34: 504-508
14. Labat-Robert J, Leutenegger M, Llopis G, Ricard Y, Berouette JC (1984) Plasma and tissue fibronectin in diabetes. Clin Physiol Biochem 2: 39-48

15. Gauss-Müller V, Kleinmann HK, Martin GF, Schiffmann E (1980) Role of attachment factors and attractants in fibroblasts chemotaxis. J Lab Clin Med 96: 1071-1080

16. Cosio FG, Sedmak DD, Nahman NS (1990) Cellular receptors for matrix proteins in normal human kidney and human mesangial cells. Kidney Int 38: 886-895

17. Border WA, Okuda S, Nakamura T (1989) Extracellular matrix and glomerular disease. Semin Nephrol 9: 307-317

18. Cohen MP, Saini R, Klepser H, Vasanthi VL (1987) Fibronectin binding to glomerular basement membrane is altered in diabetes. Diabetes 36: 758-763

19. Oberky TK, Mosher DF, Mills MD (1979) Localisation of fibronectin within the renal glomerulus and its production by cultured glomerular cells. Am J Pathol 96: 651-662

20. Musso R, Longo A, Cacciola RR, Lombardo A, Ginstrolisi R, Cacciola $E$ (1989) Elevated fibronectin plasma levels in diabetes mellitus are expression of increased synthesis and release by vascular endothelium. Thromb Haemostasis 61: 150-151

21. Phou-Thonh L, Robert L, Berouette JC, Labat-Robert J (1987) Increased biosynthesis and processing of fibronectin in fibroblasts from diabetic mice. Proc Natl Acad Sci USA 84:1911-1915

22. Hostetter TH (1986) Pathogenesis of diabetic nephropathy. In: Mitch WE, Brenner BM, Stein JH (eds) Progressive nature of renal disease. Churchill Livingstone New York, London, Melbourne, pp 149-166

23. O'Donnal MP, Kasiske BL, Cleary MP, Kean WF (1985) Effects of genetic obesity on renal structure and function in the Zucker rat. 2. Micropuncture studies. J Lab Clin Med 106: 605-610

24. Davies M, Martin J, Thomas GJ, Coles GA, Lovett DH (1987) Degradation of glomerular extracellular matrices; In: BM Price, Thudson LE, (eds) Renal basement membranes in health and disease, Academic Press, London, pp 181-201

25. Tarsio JF, Wigness B, Rhode TD, Rupp WM, Buchwald $\mathrm{H}$, Furcht LT (1985) Nonenzymatic glycation of fibronectin and alterations in the molecular association of cell matrix and basement membrane components in diabetes mellitus. Diabetes 34 : $477-484$

Received: 2 April 1991

and in revised form: 1 August 1991

Dr. M. Teschner

Medizinische Universitätsklinik

Nephrologische Abteilung

Josef-Schneider-Strasse 2

W-8700 Würzburg

FRG 